Pak. j. sci. ind. res. ser. B: biol. sci. 2016 59(1) 20-32

\title{
Preparation of Sesame Flour Supplemented High Protein and Energy Food Bars
}

\author{
Sabiha Abbas, Mian Kamran Sharif, Faiz-ul-Hassan Shah* and Rebia Ejaz \\ National Institute of Food Science \& Technology, University of Agriculture, Faisalabad-38040, Pakistan
}

(received July 22, 2015; revised October 18, 2015; accepted October 20, 2015)

\begin{abstract}
In this study, defatted sesame flour was mixed in different proportions ( $0,25,50,75$ and 100\% and given names as $\mathrm{T}_{0}, \mathrm{~T}_{1}, \mathrm{~T}_{2}, \mathrm{~T}_{3}, \mathrm{~T}_{4}$, respectively) with peanut flour and semolina to develop protein enriched sesame bars. These bars were analysed for physicochemical properties. Water activity, texture, calorific value, mineral profile, microbial examination and sensory evaluation were done at ambient temperature for 90 days. Results showed that water activity decreased from $\mathrm{T}_{0}-\mathrm{T}_{4}$ with mean values 0.6038 0.4308 , respectively. Hardness decreased within treatments from $\mathrm{T}_{0}-\mathrm{T}_{4}$ with mean values ranges from 966.86 to $211.48 \mathrm{~g}$ while, factorability increased from 70.41 to $100.33 \mathrm{~mm}$. Calorific value was also increased with maximum energy value found in $\mathrm{T}_{4}(5355.5 \mathrm{Kcal} / \mathrm{g})$ and minimum in $\mathrm{T}_{0}(3445.9 \mathrm{Kcal} / \mathrm{g})$. During storage, mold growth was increased from $3.2758 \mathrm{CFU} / \mathrm{g}\left(\mathrm{T}_{0}\right)$ to $3.6008 \mathrm{CFU} / \mathrm{g}\left(\mathrm{T}_{4}\right)$. Sensory evaluation results showed that $\mathrm{T}_{2}$ gave overall best results having moisture content $4.5 \%$, crude protein $35.73 \%$, crude fat $0.61 \%$, crude fibre $2.14 \%$, total ash $2.44 \%$ and nitrogen free extract (NFE) 46.04 .
\end{abstract}

Keywords: protein energy, malnutrition, sesame flour, supplemented flour, energy bars

\section{Introduction}

Developing countries are facing the challenges of nutritional problems, protein energy malnutrition and micronutrient deficiencies where fast growing population has resulted in limited supply of nutrients and poor sanitation conditions. The specific maladies such as Kwashiorkor and Marasmus are more prevalent in children characterised by odema, restrictions in protein intake, wasting of body tissues, particularly muscles and subcutaneous fat while in adults protein deficiency results in poor health and limited physical and mental stability (Shakeel et al., 2009).

Sesame (Sesamum indicium L.) of the family Pedaliaceae also known as gingely, beniseed, sim-sim and till, is an important annual oilseed crop in tropical countries. It is an important potential candidate for protein supplementation in cereal based foods (Alobo, 2001). The world production of sesame is estimated about 3.66 million tonnes mainly from Asia (2.55 MT) and Africa (0.95 MT). Sesame seed is called "queen of the oil seed crops, due to the high production of edible oil. Most of the sesame seeds are used for extraction of oil (Gandhi and Taimini, 2009).

Peanuts (Arachis hypogaea L.), also called groundnuts or earthnuts, is known as "The king of oilseeds". It is mainly grown in tropical and the warmer regions of the

*Author for correspondence; E-mail: faizft@yahoo.com temperate zone. It is believed to be the nature's blessing to mankind being highly nutritious, tasty and cheapest food as compared to other nuts i.e., walnuts, almonds, pistachio etc. In Pakistan, it is cultivated on an area of about 50,700 hectares, with $85 \%$ in Punjab province of Pakistan (Umar, 2006).

Semolina, a product obtained from wheat (Triticum durum) as a result of milling process in which bran and germ are removed. In Europe, finely ground semolina is used along with white flour in equal quantities to make quite dense but very flavourful bread (Palumbo et al., 2002). In Pakistan, it is usually used to make various types of sweet dishes. Pasta products, mostly consumed all over the world are conventionally manufactured from durum wheat named semolina, known to be the best raw material suitable for pasta production. It is rich source of carbohydrates (74-77\%) and its importance is rising due to its nutritional properties, predominantly low glycemic index (GI). It also has proteins $11-15 \%$ but deficient in threonine and lysine (the first and second limiting amino acids), common to most cereals (Abdel-Aal et al., 2002). This provides an opportunity for the use of non-traditional raw materials to enhance the nutritional quality of pasta (Chillo et al., 2008).

Sesame flour is an innovative, economical and traditional ingredient for the preparation of value added products. Sesame bars will not only fulfill the nutritional require- 
ments of school going children, but also act as a healthy product for all age groups. The rising trends of nutritious meals and snacks has promoted food products that combine convenience and nutrition (Izzo and Niness, 2001).

Food products developed through supplementation of defatted sesame and peanut flour provides balanced amount of amino acids required for human body. The present study therefore, has been designed to develop high energy and nutritious bar as an alternative to conventional snacks using sesames indigenous sources. Sesame flour supplemented high protein and energy food bars were prepared and examined to find out their acceptability through physicochemical analysis and sensory evaluation.

\section{Materials and Methods}

Procurement and preparation of raw materials. Sesame cultivar (TH-6, White till) were procured from Ayub Agricultural Research Institute (AARI), Faisalabad, Pakistan while other materials required for the preparation of sesame bar e.g. peanut, suji (semolina), coconut, edible oil and sugar were procured from local market. All reagents (analytical) were procured from Merck (Merck KGa A, Darmstadt, Germany) and SigmaAldrich (Sigma Aldrich, Tokyo, Japan). Sesame seeds were partially defatted by using hydraulic press and ground to flour. Coconut were reduced in size by crushing. Peanuts were converted into peanut flour after roasting and grinding. All flours were packed in polyethylene bags and stored at room temperature for further analysis and utilization.

Analysis of raw materials. Sesame flour along with peanut flour and semolina were analysed in triplicate for moisture content, crude protein, crude fat, crude fibre, ash content and nitrogen free extract (NFE) by following respective methods as described in AACC (2000).

Mineral analysis. Raw materials (sesame flour, peanut flour and semolina) were analysed for mineral profile. Each treatment was analysed for $\mathrm{Na}, \mathrm{K}, \mathrm{Ca}$, and $\mathrm{Fe}$ through flame photometer (Sherwood Scientific Ltd., Cambridge) and atomic absorption spectrophotometer (Varian AA240, Australia) by following procedure of AOAC (2006).

Preparation of sesame flour supplemented food bars. Roasted sesame flour, peanut flour, coconut flour, semolina, oil and sugar were mixed on mild heating for
20-30 mins to make a uniform blend. After cooling sheeting were done followed by cutting into bars maintaining a specific size, shape and thickness. Finally bars were baked at $175^{\circ} \mathrm{C}$ for $20-25$ mins followed by packing in aluminium foil. Sesame flour was supplemented in different proportions (Table 1) with remaining ingredients like peanut flour, suji, coconut, sugar and oil kept constant and all compositions were utilized for the preparation of sesame flour supplemented bars.

Table 1: Experimental treatments used for sesame bars

\begin{tabular}{ll}
\hline \hline Treatments & Supplementation of sesame flour (\%) \\
\hline $\mathrm{T}_{0}$ & 0 \\
$\mathrm{~T}_{1}$ & 25 \\
$\mathrm{~T}_{2}$ & 50 \\
$\mathrm{~T}_{3}$ & 75 \\
$\mathrm{~T}_{4}$ & 100 \\
\hline \hline
\end{tabular}

Analysis and shelf life study of bars. Sesame flour supplemented bars prepared from all compositions were stored at room temperature $\left(25-30{ }^{\circ} \mathrm{C}\right)$ and analysed for physicochemical, mineral profile, microbial examination, calorific value and sensory evaluation at $0,30,60$, and 90 days storage interval and the results are summerized in Table 1-9.

Proximate analysis. Sesame flour supplemented food bars were analysed for moisture content, crude protein, crude fat, crude fibre, ash content and NFE according to respective methods given in AACC (2000).

Water activity. An electronic hygropalm water activity meter (Model Aw-Win, Rotronic, equipped with a KarlFast probe) was used for estimating the water activity of the sesame flour supplemented food bars at regular storage intervals. Hygropalm water activity meter was caliberated and sesame bars were analysed (AOAC, 1998).

Texture analysis. Texture of bars was determined at different storage intervals according to the method as described by Rehman and Al-Farsi (2005) with some modifications by using a texture analyser (Model TAXT) plus Stable Microsystems (Surrey, UK) with $5 \mathrm{~kg}$ load cell.

Colour measurement. A hand held colorimeter tristimulus colorimeter (colour Test Meter II, Neohaus Neotec) was used to determine the colour of sesame flour supplemented food bars at regular storage intervals 
according to the method described by Rocha and Morais (2003).

Mineral profile. Samples of sesame bars were analysed for mineral profile according to the procedures given in AOAC (2006).

Mold growth. Mold growth was done according to the method as described in method 42-50 (AACC, 2000).

Calorific value. Calorific values of the bars were determined by using oxygen bomb calorimeter (IKAWERKE, C2000 Basic) as described by Krishna and Ranjhan (1981).

Sensory evaluation. Sesame flour supplemented food bars were evaluated for sensory characteristics such as colour, flavour, texture, crispiness, chewability and overall acceptability at room temperature (i.e. $25-30^{\circ} \mathrm{C}$ ) for a storage period of three months in a sensory evaluation laboratory by a panel of five judges on 9-point Hedonic scale (Meilgaard et al., 2006).

Statistical analysis. The results obtained for each parameter were subjected to statistical analysis to determine the level of significance according to the methods described by Steel et al. (1997)

\section{Results and Discussion}

Raw materials analysis. Proximate analysis. Defatted sesame flour subjected to proximate composition (Table 2) indicated that it comprises of moisture $2.19 \pm 0.02 \%$, crude protein $51.5 \pm 0.4 \%$, crude fibre $3.45 \pm 0.03 \%$, ash $6.14 \pm 0.09 \%$, crude fat $1.49 \pm 0.03 \%$ and $45.56 \pm 0.19$ NFE. Onsaard et al. (2010) reported that defatted sesame flour contains moisture $2.19 \%$, crude protein $50.45 \%$, crude fibre $3.46 \%$, ash $6.15 \%$, crude fat $1.49 \%$ and
NFE 45.56. These results were in conformity with the composition of defatted sesame flour assessed.

Peanuts (Arachis hypogaea L.) under proximate analysis showed moisture $4.5 \pm 0.03 \%$, crude fat $46.18 \pm 0.13 \%$, crude protein $30.59 \pm 0.31 \%$, crude fibre $3.87 \pm 0.08 \%$, ash $2.72 \pm 0.21 \%$ and NFE $9.64 \pm 0.27 \%$. The earlier findings of Atasie et al. (2009) were found in accordance with the composition results who reported that peanut contains crude fat $45 \%$, crude protein $36 \%$, moisture $6.1 \%$, crude fibre $3.25 \%$, ash $2.9 \%$ and NFE $6.75 \%$.

Chemical composition of semolina revealed that, it contains moisture $11.22 \pm 0.06 \%$, crude protein 13.86 $\pm 0.17 \%$, crude fat $0.2 \pm 0.01 \%$, ash $0.82 \pm 0.05 \%$, crude fiber $0.7 \pm 0.02 \%$ and NFE $73.2 \pm 0.15 \%$. The composition of semolina was found in concurrence with the earlier findings of Hussein et al. (2011), who reported that semolina contains moisture $12 \%$, crude protein $14 \%$, crude fat $0.4 \%$, ash $0.9 \%$, crude fibre $0.6 \%$ and NFE $73.6 \%$.

Mineral analysis. Defatted sesame flour subjected to mineral composition (Table 2 ) indicated that, it comprises of $\mathrm{K}(385 \pm 0.3 \mathrm{mg} / 100 \mathrm{~g}), \mathrm{Na}(7.63 \pm 0.9 \mathrm{mg} / 100 \mathrm{~g})$, $\mathrm{Fe}(6.19 \pm 0.21 \mathrm{mg} / 100 \mathrm{~g})$ and $\mathrm{Ca}(20.3 \pm 0.9 \mathrm{mg} / 100 \mathrm{~g})$. Hahm et al. (2009) reported that, defatted sesame flour contains K (382mg/100g), Na (7.60 mg/100g), Fe (6.17 $\mathrm{mg} / 100 \mathrm{~g})$ and $\mathrm{Ca}(420 \mathrm{mg} / 100 \mathrm{~g})$. These results were in conformity with the composition of defatted sesame flour assessed.

Peanuts (Arachis hypogaea L.) under mineral analysis showed that, they contain $\mathrm{K}(38.5 \pm 0.4 \mathrm{mg} / 100 \mathrm{~g}), \mathrm{Na}$ $(22.6 \pm 0.6 \mathrm{mg} / 100 \mathrm{~g}), \mathrm{Fe}(0.8 \pm 0.03 \mathrm{mg} / 100 \mathrm{~g})$ and $\mathrm{Ca}$ $(21.4 \pm 0.72 \mathrm{mg} / 100 \mathrm{~g})$. Findings of Vincent et al. (2009) were in accordance with the composition results, who

Table 2: Proximate composition and mineral analysis of raw materials

\begin{tabular}{lllllll}
\hline \hline \multirow{2}{*}{ Raw materials } & \multicolumn{5}{c}{ Proximate composition (\%) } \\
\cline { 2 - 5 } Defatted sesame flour & Moisture & Protein & Fat & Fibre & Ash & NFE \\
Peanut flour & $2.19 \pm 0.02$ & $51.5 \pm 0.4$ & $1.49 \pm 0.03$ & $3.46 \pm 0.03$ & $6.15 \pm 0.09$ & $45.56 \pm 0.19$ \\
Semolina & $4.5 \pm 0.03$ & $30.59 \pm 0.31$ & $46.18 \pm 0.13$ & $3.87 \pm 0.08$ & $2.72 \pm 0.21$ & $9.64 \pm 0.27$ \\
Raw materials & $11.22 \pm 0.06$ & $13.86 \pm 0.17$ & $0.2 \pm 0.01$ & $0.7 \pm 0.02$ & $0.82 \pm 0.05$ & $73.2 \pm 0.15$ \\
\cline { 2 - 5 } & Potassium $(\mathrm{K})$ & Sodium $(\mathrm{Na})$ & Iron $(\mathrm{Fe})$ & Calcium $(\mathrm{Ca})$ & - & - \\
\hline Defatted Sesame flour & $385 \pm 0.3$ & $7.63 \pm 0.9$ & $6.19 \pm 0.21$ & $20.3 \pm 0.9$ & - & - \\
Peanut flour & $38.5 \pm 0.4$ & $22.6 \pm 0.6$ & $0.8 \pm 0.03$ & $21.4 \pm 0.72$ & - & - \\
Semolina & $3.20 \pm 0.6$ & $8.53 \pm 0.3$ & $41.5 \pm 0.45$ & $278 \pm 0.52$ & - & - \\
\hline \hline
\end{tabular}

$\mathrm{NFE}=$ nitrogen free extract. 
reported that peanut contains $\mathrm{K}(38.1 \mathrm{mg} / 100 \mathrm{~g})$, Na $(22.0 \mathrm{mg} / 100 \mathrm{~g}), \mathrm{Fe}(0.78 \mathrm{mg} / 100 \mathrm{~g})$ and $\mathrm{Ca}(21.1 \mathrm{mg} /$ $100 \mathrm{~g})$.

Mineral composition of semolina revealed that it contains, $\mathrm{K}(3.20 \pm 0.6 \mathrm{mg} / 100 \mathrm{~g}), \mathrm{Na}(8.53 \pm 0.3$ $\mathrm{mg} / 100 \mathrm{~g}), \mathrm{Fe}(41.5 \pm 0.45 \mathrm{mg} / 100 \mathrm{~g})$ and $\mathrm{Ca}(278 \pm$ $0.52 \mathrm{mg} / 100 \mathrm{~g}$ ). The mineral composition of semolina was found inaccordance with the earlier findings of Cubadda et al. (2009), accordance who reported that semolina contains $\mathrm{K}(3.18 \mathrm{mg} / 100 \mathrm{~g}), \mathrm{Na}(8.51 \mathrm{mg} / 100 \mathrm{~g})$, $\mathrm{Fe}(41.1 \mathrm{mg} / 100 \mathrm{~g})$ and $\mathrm{Ca}(276 \mathrm{mg} / 100 \mathrm{~g})$.

Moisture content. Moisture of the sesame bars was observed to be highly significant among the treatments. These formulations of sesame bars contained different concentrations of defatted sesame flours at regular storage intervals and ambient temperature were statistically analysed for moisture content ranging from $5.63 \pm 0.02$ to $3.65 \pm 0.05 \%$ Table 3 . The mean values for moisture content of various sesame bars treatments reveal the peak score for $T_{0}$ and the minimum score for $\mathrm{T}_{4}$. During storage period, the moisture difference was significantly high as well. Having the highest moisture content at 0 day and gradually decreasing to 90 days where it was the lowest, the mean values for storage ranged from $4.73 \pm 0.71$ to $4.17 \pm 0.56 \%$ (Table 4 ) similar to the results in water activity of the sesame bars. There was a steady decrease in moisture content with increasing concentration of defatted sesame flour in treatments. Decrease in the moisture of the sesame bars was vastly significant, possibly due to desertion of water from the products, as a result of two main factors i.e. increased temperature during the hot weather and exposure to the atmosphere at times. Analogous to the case in water activity, moisture content in the last two treatments $T_{3}$ and $T_{4}$ containing higher concentration of defatted sesame flour showed greater reduction in moisture as compared to treatments containing lower concentration of defatted sesame flour i.e. $T_{1}$ and $T_{2}$. It could be possible due to the presence of oil in $T_{3}$ and $\mathrm{T}_{4}$ which does not have the tendency to hold water. Also there was highly significant effect of treatment and storage interaction on moisture contents of sesame bars. Outcomes of moisture fluctuations during storage for various treatments is in agreement with the results of Gandhi and Taimini (2009) that moisture content decreased significantly in cereal nut bars from 7.75$6.39 \%$ during storage of 30 days at ambient temperature. Results were contradictory to those of Estevez et al. (1998), who reported that moisture content remained similar i.e., 7.6-9.6\% with no significant storage change in cereal nut bars during a storage period of 90 days at $18-20^{\circ} \mathrm{C}$. Low temperature could be the possible reason for constant moisture content during the storage period.

Table 3: Effect of treatments on proximate composition and mineral profile of sesame bars

\begin{tabular}{lllllll}
\hline \hline Treatments & \multicolumn{7}{c}{ Proximate analysis (\%) } \\
\cline { 2 - 6 } & Moisture & Protein & Fat & Fibre & Ash & NFE \\
\hline $\mathrm{T}_{0}$ & $5.63 \pm 0.02 \mathrm{a}$ & $33.69 \pm 0.12 \mathrm{e}$ & $0.64 \pm 0.13 \mathrm{c}$ & $1.93 \pm 0.81 \mathrm{~d}$ & $2.67 \pm 0.03 \mathrm{~b}$ & $46.04 \pm 0.61 \mathrm{c}$ \\
$\mathrm{T}_{1}$ & $4.99 \pm 0.07 \mathrm{~b}$ & $35.57 \pm 0.23 \mathrm{~d}$ & $0.61 \pm 0.08 \mathrm{~d}$ & $1.86 \pm 0.71 \mathrm{e}$ & $2.13 \pm 0.08 \mathrm{e}$ & $44.85 \pm 0.53 \mathrm{e}$ \\
$\mathrm{T}_{2}$ & $4.53 \pm 0.04 \mathrm{c}$ & $35.73 \pm 0.15 \mathrm{c}$ & $0.61 \pm 0.09 \mathrm{~d}$ & $2.14 \pm 0.07 \mathrm{c}$ & $2.44 \pm 0.03 \mathrm{~d}$ & $46.04 \pm 0.43 \mathrm{c}$ \\
$\mathrm{T}_{3}$ & $3.73 \pm 0.09 \mathrm{~d}$ & $35.90 \pm 0.17 \mathrm{~b}$ & $0.77 \pm 0.11 \mathrm{~b}$ & $2.34 \pm 0.21 \mathrm{~b}$ & $2.62 \pm 0.09 \mathrm{c}$ & $46.93 \pm 0.27 \mathrm{~b}$ \\
$\mathrm{~T}_{4}$ & $3.65 \pm 0.05 \mathrm{~d}$ & $36.19 \pm 0.23 \mathrm{a}$ & $0.97 \pm 0.05 \mathrm{a}$ & $2.54 \pm 0.31 \mathrm{a}$ & $3.43 \pm 0.11 \mathrm{a}$ & $49.17 \pm 0.21 \mathrm{a}$ \\
\hline & & Mineral Profile $(\mathrm{mg} / 100 \mathrm{~g})$ & & & \\
& & & & & & \\
\hline $\mathrm{T}_{0}$ & $384.48 \pm 9.21 \mathrm{~d}$ & $46.46 \pm 0.52 \mathrm{c}$ & $10.22 \pm 0.04 \mathrm{a}$ & $61.59 \pm 2.34 \mathrm{~b}$ & & \\
$\mathrm{~T}_{1}$ & $362.03 \pm 8.26 \mathrm{e}$ & $44.11 \pm 0.91 \mathrm{~d}$ & $7.49 \pm 0.06 \mathrm{~b}$ & $55.65 \pm 1.56 \mathrm{~d}$ & & \\
$\mathrm{~T}_{2}$ & $486.75 \pm 5.41 \mathrm{c}$ & $38.20 \pm 0.74 \mathrm{e}$ & $7.90 \pm 0.06 \mathrm{~b}$ & $52.86 \pm 3.56 \mathrm{e}$ & & \\
$\mathrm{T}_{3}$ & $511.69 \pm 8.19 \mathrm{~b}$ & $48.77 \pm 0.75 \mathrm{~b}$ & $6.48 \pm 0.02 \mathrm{c}$ & $60.26 \pm 2.45 \mathrm{c}$ & & \\
$\mathrm{T}_{4}$ & $555.96 \pm 6.53 \mathrm{a}$ & $51.28 \pm 0.48 \mathrm{a}$ & $5.35 \pm 0.08 \mathrm{~d}$ & $67.27 \pm 1.78 \mathrm{a}$ & & \\
\hline \hline
\end{tabular}

Means carrying same letters in a column for each factor do not differ significantly; NFC $=$ nitrogen free extract; $\mathrm{T}_{0}=0 \%$ supplementation of defatted sesame flour; $\mathrm{T}_{1}=25 \%$ supplementation of defatted sesame flour; $\mathrm{T}_{2}=50 \%$ supplementation of defatted sesame flour; $\mathrm{T}_{3}=75 \%$ supplementation of defatted sesame flour; $\mathrm{T}_{4}=100 \%$ supplemen-tation of defatted sesame flour. 
Crude protein. Protein content differed significantly along the various treatments of the sesame bars according to the statistical results. Table 3 demonstrates the statistical analysis for protein content of different treatments of sesame bars containing assorted concentrations of defatted sesame flours at storage intervals $(0,30,60$ and 90 days). Mean values for protein contents of sesame bars samples ranged from $33.69 \pm 0.12$ to 36.19 $\pm 0.23 \%$, with $\mathrm{T}_{0}$ having the least protein content and $\mathrm{T}_{4}$ with the highest protein score. Gradual increase in protein contents with increasing concentrations of defatted sesame flour in treatments was evident from the results. The mean values for treatments also reveal that treatments $T_{3}$ and $T_{4}$ have significantly higher protein content due to increased quantity of defatted sesame flour used. A non significant effect of storage on protein contents of sesame bars was calculated by the mean values for storage ranged from $35.35 \pm 0.65$ to $35.48 \pm 0.24 \%$ during 90 days storage period as illustrated in Table 4. There were non-significant effect of treatment and storage interaction on protein contents of sesame bars.

Variation in protein content during storage for various treatments is in conformity with the findings of Khalil (1986), who reported that in sesame bars fortified with almonds, skim milk powder, soy protein isolate and single cell proteins, protein content was increased from $4.9-5.3 \%$ in the control to $10.7-12.1 \%$ in samples containing the high protein ingredients. These supplemented sesame bars not only increased protein content but also possess significantly higher chemical scores and essential amino acids. The protein content changed non-significantly in legume and vegetable based soup powder from $19.35 \%-19.45 \%$ according to Rokhshana et al. (2007) during storage of 6 months. Protein results obtained in the present study are compatible with these findings.

Crude fat. Different treatments of sesame bars containing varied concentrations of defatted sesame flour at regular storage intervals at ambient temperature were statistically analysed for fat content and are presented in Table 3. The results in the variation in fat content among different treatments are highly significant. Treatment $T_{4}$ had the maximum score where as $T_{0}$ having the least score was deducted by the mean values for treatments which ranged from $0.64 \pm 0.13-0.97 \pm$ $0.05 \%$. The mean value for fat contents of sesame bars samples have been presented in Table 3. Evidently from the results, it is affirmed that there was a gradual increase in fat contents with increasing concentration of defatted sesame flours in all the treatments but obviously $\mathrm{T}_{3}$ and $\mathrm{T}_{4}$ had more fat content due to the manual inclusion of fat in them used for frying. There was highly significant effect of storage days on fat contents of sesame bars where the mean values ranged from $0.63 \pm 0.03$ to 0.77 $\pm 0.03 \%$ in Table 4 . There was highly significant effect of treatment and storage interaction on fat contents of sesame bars. Similar findings were obtained by Goni and Gamazo (2002) who reported that fat content increased from $1.81-2.60 \%$ in wheat pasta after incorporation of chickpea flour in it.

Table 4: Effect of storage on the proximate and mineral profile of sesame bars

\begin{tabular}{lllllll}
\hline \hline \multirow{2}{*}{$\begin{array}{l}\text { Storage } \\
\text { intervals }\end{array}$} & \multicolumn{5}{c}{ Proximate analysis (\%) } \\
\cline { 2 - 6 } & Moisture & Protein & Fat & Fibre & Ash & NFE \\
\hline $\mathrm{S}_{0}$ & $4.73 \pm 0.71 \mathrm{a}$ & $35.35 \pm 0.65 \mathrm{~d}$ & $0.63 \pm 0.03 \mathrm{~d}$ & $2.09 \pm 0.92 \mathrm{~d}$ & $2.49 \pm 0.72 \mathrm{~d}$ & $46.01 \pm 3.12 \mathrm{~d}$ \\
$\mathrm{~S}_{30}$ & $4.63 \pm 0.67 \mathrm{ab}$ & $35.40 \pm 0.24 \mathrm{c}$ & $0.67 \pm 0.03 \mathrm{c}$ & $2.15 \pm 0.78 \mathrm{c}$ & $2.65 \pm 0.91 \mathrm{c}$ & $46.36 \pm 2.15 \mathrm{c}$ \\
$\mathrm{S}_{60}$ & $4.52 \pm 0.24 \mathrm{~b}$ & $35.44 \pm 0.45 \mathrm{~b}$ & $0.71 \pm 0.06 \mathrm{~b}$ & $2.20 \pm 0.82 \mathrm{~b}$ & $2.73 \pm 0.76 \mathrm{~b}$ & $46.76 \pm 4.63 \mathrm{~b}$ \\
$\mathrm{~S}_{90}$ & $4.17 \pm 0.56 \mathrm{c}$ & $35.48 \pm 0.24 \mathrm{a} \mathrm{a}$ & $0.77 \pm 0.03 \mathrm{a}$ & $2.24 \pm 0.56 \mathrm{a}$ & $2.79 \pm 0.34 \mathrm{a}$ & $47.07 \pm 2.96 \mathrm{a}$ \\
\hline & & Mineral Profile $(\mathrm{mg} / 100 \mathrm{~g})$ & & \\
& & & & & & \\
& Potassium & Sodium & Iron & Calcium & & \\
$\mathrm{S}_{0}$ & $459.59 \pm 14.24 \mathrm{c}$ & $45.69 \pm 3.93 \mathrm{~d}$ & $8.09 \pm 0.72 \mathrm{a}$ & $59.45 \pm 3.67 \mathrm{~d}$ & & \\
$\mathrm{~S}_{30}$ & $459.74 \pm 18.96 \mathrm{c}$ & $45.74 \pm 1.46 \mathrm{c}$ & $8.01 \pm 0.56 \mathrm{a}$ & $59.50 \pm 1.95 \mathrm{c}$ & & \\
$\mathrm{S}_{60}$ & $460.47 \pm 15.78 \mathrm{~b}$ & $45.79 \pm 2.56 \mathrm{~b}$ & $6.46 \pm 0.73 \mathrm{c}$ & $59.56 \pm 2.83 \mathrm{~b}$ & & \\
$\mathrm{~S}_{90}$ & $460.93 \pm 17.93 \mathrm{a}$ & $45.85 \pm 3.72 \mathrm{a}$ & $7.42 \pm 0.92 \mathrm{~b}$ & $59.62 \pm 1.57 \mathrm{a}$ & & \\
\hline \hline
\end{tabular}

Means carrying same letters in a column for each factor do not differ significantly; NFE = nitrogen free extract; $\mathrm{S}_{0}=0$ day; $\mathrm{S}_{30}=30$ days; $\mathrm{S}_{60}=60$ days; $\mathrm{S}_{90}=90$ days. 
Crude fibre. Fibre content differentiation was highly significant among various treatments of the sesame bars according to the statistical results. Table 3 demonstrates the statistical analysis for fibre content of different treatments of sesame bars containing assorted concentrations of defatted sesame flour at storage intervals $(0,30,60$ and 90 days). The mean values of fibre contents for treatments, ranged from $1.93 \pm 0.81$ to 2.54 $\pm 0.31 \%$ having the lowest score for $\mathrm{T}_{0}$ and the highest score in case of $\mathrm{T}_{4}$. There was a gradual increase in fibre contents with increasing concentrations of defatted sesame flour in treatments according to the results. Treatments $\mathrm{T}_{3}$ and $\mathrm{T}_{4}(2.34 \pm 0.21$ and $2.54 \pm 0.31 \%)$ due to increased quantity of defatted sesame flour, showed higher results of fibre percentage as compared to $T_{1}$ and $T_{2}(1.93 \pm 0.81$ and $1.86 \pm 0.71)$. Higher dry matter in the sesame bars was seen by the mean values of fibre contents for storage periods ranged from 2.09 \pm 0.92 to $2.24 \pm 0.56 \%$ from 0 to 90 days in Table 4 . There was significant effect of treatment and storage interaction on fibre content of sesame bars. The change of fibre during storage for various treatments is in conformity with the findings of Rokhsana et al. (2007) who reported that fibre content changed non-significantly in legume and vegetable based soup powder from 0.65 $0.70 \%$ during storage of 6 months.

Ash content. The analysis of variance for ash contents of different treatments of sesame bars containing varied concentrations of defatted sesame flours at regular intervals showed that the difference in ash contents among different treatments is highly significant (Table $3)$. The mean values of ash contents for treatments ranged from $2.67 \pm 0.03$ to $3.43 \pm 0.11 \%$ having the lowest ash contents for $\mathrm{T}_{0}$ and the highest ash content in $\mathrm{T}_{4}$. There was a gradual increase in ash contents with increasing concentrations of defatted sesame flour in treatments and results show that treatments $\mathrm{T}_{3}$ and $\mathrm{T}_{4}$, due to increased quantity of defatted sesame flour, showed higher results of ash percentage $(2.62 \pm 0.03$ to $3.43 \pm 0.11 \%)$ as compared to $\mathrm{T}_{1}$ and $\mathrm{T}_{2}(2.13 \pm 0.08$ to $2.44 \pm 0.03 \%$ ) as depicted in Table 3 . This could also be due to higher dry matter in the sesame bars of $\mathrm{T}_{3}$ and $\mathrm{T}_{4}$. Regarding the dry matter i.e. defatted sesame flour in the sesame bars, ash content is directly related to the fibre content of the sesame bars. There was a highly significant effect of storage days on ash contents of sesame bars. The mean values of ash contents for storage period ranged from $2.49 \pm 0.72$ to $2.79 \pm 0.34 \%$ for 0 to 90 days (Table 4). There was a highly significant effect of treatment and storage interaction on ash contents of sesame bars. Results are also in accordance with Gandhi and Taimini (2009) who reported that ash contents were not affected by storage conditions in sesame bars.

Nitrogen free extract (NFE). The data presented in Table 3 showed that NFE among treatments and during storage were highly significant. The interaction of treatment and storage was also highly significant. In Table 3 the mean values of NFE of different treatments showed that minimum NFE was found in $\mathrm{T}_{0}$ that was $46.04 \pm 0.61$ and maximum was found in $T_{4}$ which was $49.17 \pm 0.21$. The mean values of NFE contents of supplemented flour showed in Table 4 at 0, 30, 60 and 90 days interval were $46.01 \pm 3.12,46.36 \pm 2.15,46.76$ \pm 4.63 and $47.07 \pm 2.96$. The interaction of storage period into treatments showed that the highest NFE value $49.17 \pm 0.21$ was found in $\mathrm{T}_{4}$ and the lowest NFE value $46.04 \pm 0.61$ was observed in $T_{0}$ at 90 days of storage period. With the passage of time NFE increased significantly. This is due to increase in fat and protein content. The increasing trend in flours during storage is also observed by Gandhi and Taimini (2009).

Physical characteristics of sesame bars. Water activity. Water activity fluctuated significant during storage days, ranging the mean values from $0.53 \pm 0.08$ to $0.49 \pm$ 0.67 for 0 to 90 days, respectively, in Table 7 . Water activity among all the treatments naturally decreased due to the decrease in moisture content during storage, as a result of high temperature in the summer. Comparing the defatted sesame flour treatments $\mathrm{T}_{3}$ and $\mathrm{T}_{4}(0.46$ and 0.43$)$ with treatments $T_{0}$ and $T_{1}(0.60$ and 0.55$)$, possibly reveal that $T_{3}$ and $T_{4}$ have lower water activity because of inclusion of vegetable oil in the treatments which could be helpful in binding the water present in the sesame bars. There was a highly significant effect of treatment and storage interaction on water activity of defatted sesame flour bars.

During storage the variation of water activity in various treatments is in compliance with the findings of Estevez et al. (1998) in the cereal and nut bars, who informed that water activity significantly reduced in the bars from 0.71-0.52 during storage of 60 days. Similar results were obtained in Amaretti cookies by Piga et al. (2005) who reported water activity 0.54 at the start which progressively decreased to 0.40 after storage of 35 days at ambient temperature.

Texture. Two properties of texture were observed i.e., initially hardness of the bars which is described in terms 
of the maximum force $(\mathrm{g})$ and fracturability in terms of distance $(\mathrm{mm})$ necessary for the texture analyzer probe to travel through the bars. Reflecting significant differences in the hardness and fracturability of the various sesame bars, the statistical analysis of defatted sesame flour at storage intervals $(0,30,60$ and 90 days) are given in Table 7 . The mean values of hardness for treatments ranged from 966.86-211.48 g, having the lowest mark for $\mathrm{T}_{0}$ and the maximum mark in case of $\mathrm{T}_{4}$ (Table 7) and fracturability ranged from 70.41-100.33 $\mathrm{mm}$ having the least score for $\mathrm{T}_{0}$ and the highest rank in case of $\mathrm{T}_{4}$. Increasing concentrations of defatted sesame flour in various treatments apparently resulted in a gradual increase in hardness and fracturability. Hardness of sesame bars increased from 0-30 days progressively. This trend gradually decreased from $60-$ 90 days thereby, decreasing hardness. On the other hand fracturability increased in smooth way from 0-90 days and a relationship with hardness was observed, concluding a highly significant effect of storage days on texture of sesame bars. In general, this might be due to the moisture loss to the atmosphere from the sesame bars but treatments $\mathrm{T}_{3}$ and $\mathrm{T}_{4}$ were harder in texture due to cooking treatment which hardened the texture due to excess moisture loss. Thereby, there was a highly significant effect of treatment and storage on hardness and fracturability of sesame bars. The variation of texture during storage for various treatments is in conformity with the hardness that significantly changed rather decreased in Amaretti cookies from 59-383 N during storage of 35 days (Piga et al., 2005).

Colour measurement. At regular storage intervals ( 0 , 30, 60 and 90 days) under ambient temperature, the colour values of various treatments of sesame bars containing different concentrations of defatted sesame flour were statistically analysed and are given in Table 7. The observed results obviously reveal that the differences in colour values are highly significant amongst different treatments. The treatment $T_{0}$ having the lowest score and the highest score in case of $\mathrm{T}_{4}$ were increased from the range of mean values of colour from 87.00-180.00 CTn in the treatments. The means for colour values of sesame bars samples have been presented in Table 7. Results apparently show that there was a continual increase in colour values with increased concentrations of defatted sesame flour addition in the bars i.e., greater the amount of defatted sesame flour, higher the colour value. The mean values for storage phase ranged from $125.60 \pm 6.21$ to $155.60 \pm 7.23 \mathrm{CTn}$ for 0-90 days, respectively, showing that there was a highly significant effect of storage on colour of sesame bars as shown in Table 7. The treatments $T_{3}$ and $T_{4}$ containing greater amounts of defatted sesame flour have significantly higher colour values 141.00-180.00 $C T n$ as compared to $T_{0}$ and $T_{1}$ containing lesser amount of depatted sesame flour therefore, having lower colour values $87.00-143.00 \mathrm{CTn}$, which is due to the increase in the quantity of defatted sesame flour used in $\mathrm{T}_{3}$ and $\mathrm{T}_{4}$. The results of treatment and storage periods interaction on colour of sesame bars is non-significant. The colour of the bars during storage could be influenced by the Maillard reactions, leading to darken the sesame bars with the passage of time.

Comparing the results with the earlier deductions illustrate that the alteration of colour during storage for various treatments is in conformity with the findings of McMahon et al. (2002) who reported that during storage period of 42 days colour changed significantly in high whey protein nutritious bars from 54.73 to 70.30 , as the bars became darken in colour during storage depending upon the Maillard reactants.

\section{Mineral profile of sesame bars. Potassium content.} Potassium is an important intracellular cation in the body that plays a vital role in the maintenance of energy metabolism, cell membrane potential and membrane transport of other ions. Because of its role in these processes, optimum potassium intake is vital for the contraction of muscle groups such as the heart.

Potassium content difference was highly significant amongst several treatments on statistical analysis for potassium content of the sesame bars treatments containing different concentrations of defatted sesame flour at storage intervals $(0,30,60$ and 90 days $)$ as shown in Table 3. The mean values for treatments in Table 3 ranged from $384.48 \pm 9.21 \mathrm{mg} / 100 \mathrm{~g}$ having the least potassium content for $\mathrm{T}_{0}$ to $555.96 \pm 6.53 \mathrm{mg} / 100 \mathrm{~g}$ the highest potassium content in case of $\mathrm{T}_{4}$. Results reveal that there was a gradual increase in potassium content with increasing concentrations of defatted sesame flour among treatments and $\mathrm{T}_{3}$ and $\mathrm{T}_{4}$ have a greater potassium content score $(511.69 \pm 8.19$ and $555.96 \pm 6.53 \mathrm{mg} / 100 \mathrm{~g}$ ) as compared to $\mathrm{T}_{0}$ and $\mathrm{T}_{1}$ $(384.48 \pm 9.21$ and $362.03 \pm 8.26 \mathrm{mg} / 100 \mathrm{~g})$. A highly significant effect of storage on potassium content of sesame bars was observed by the mean values for storage ranged from $459.59 \pm 14.24$ to $460.93 \pm 17.93 \mathrm{mg} / 100 \mathrm{~g}$ from 0 to 90 days, respectively, in Table 4. Effect of 
treatment and storage interaction on potassium content of the sesame bars was non-significant, more likely due to its metabolizing disability, which in turn shows no alteration in the potassium content during storage. Change in potassium content during storage for various treatments is in conformity with the findings of (Ismail et al., 2008) who reported that potassium content changed non-significantly in cereal and nuts bars during 1 year storage period at room temperature.

Sodium content. Sodium content of different treatments of sesame bars when subjected to statistical analysis reveals a highly significant effect of these treatments on the sodium content of these bars containing different concentrations of defatted sesame flour at ambient temperature at regular storage intervals $(0,30,60$ and 90 days). It is elaborated in Table 3 along with the mean values of sodium content for treatments that the maximum marks $51.28 \pm 0.48 \mathrm{mg} / 100 \mathrm{~g}$ is in case of $\mathrm{T}_{4}$ and the least score $46.46 \pm 0.52 \mathrm{mg} / 100 \mathrm{~g}$ is for $\mathrm{T}_{0}$. Results reveal that with increasing concentrations of defatted sesame flour among treatments, there was a steady increase in sodium content. The mean values for storage ranging from $45.69 \pm 3.93$ to $45.84 \pm 3.72$ $\mathrm{mg} / 100 \mathrm{~g}$ from 0-90 days, respectively, showed highly significant effect of storage on sodium content of sesame bar in Table 4. Also the effect of treatment and storage interaction on sodium content of sesame bars was significant. The results are in accordance with Ismail et al. (2008) that treatments and storage interaction are highly significant.

Iron content. Iron is an essential element and its physiological losses must be compensated regularly (Yip and Dallman, 1996). Iron content difference was highly significant on statistical analysis of various treatments of sesame bars containing different concentrations of defatted sesame flour at storage intervals $(0,30.60$ and 90 days $)$ at ambient temperature. Table 3 elaborates the mean values of iron content for treatments ranging from the highest score $10.22 \pm 0.04$ $\mathrm{mg} / 100 \mathrm{~g}$ in case of $\mathrm{T}_{0}$ and the lowest score $5.35 \pm 0.08$ $\mathrm{mg} / 100 \mathrm{~g}$ for $\mathrm{T}_{4}$. A highly significant effect of storage on iron content of sesame bars was observed by the mean values for storage ranging from $8.09 \pm 0.72$ to 7.42 $\pm 0.92 \mathrm{mg} / 100 \mathrm{~g}$ at 0-90 days, respectively (Table 4). Effect of treatment and storage interaction on iron content was also highly significant. The iron content changed significantly in legume and vegetable based soup powder from $26.75-25.77 \mathrm{mg} / 100 \mathrm{~g}$ during 6 months storage period at room temperature in the findings of Rokhsana et al. (2007) which happen to be similar to the iron content variations in the sesame bars during storage.

Calcium content. Calcium content varied highly significant amongst the various treatments in conclusion to the statistical analysis different treatments of sesame bars containing varied concentrations of defatted sesame flour as illustrated in Table 3, at regular storage intervals (0, 30, 60 and 90 days). Table 3 presents the mean values of calcium content for treatments ranging from $61.59 \pm 2.34$ to $67.27 \pm 1.78 \mathrm{mg} / 100 \mathrm{~g}$, having the lowest calcium content for $\mathrm{T}_{0}$ and the highest in case of $\mathrm{T}_{4}$. A gradual increase in calcium content, owing to increasing concentrations of defatted sesame flour among treatments is evident from the results. The mean values for storage ranged from $59.45 \pm 3.67$ to 59.62 $\pm 1.57 \mathrm{mg} / 100 \mathrm{~g}$ from $0-90$ days, respectively, in Table 4. There was highly significant effect of storage and significant effect of treatment-storage interaction on calcium content of sesame bar. Calcium content changed during storage for sesame bars treatments is in conformity with the findings of Rokhsana et al. (2007) who reported that calcium content changed nonsignificantly in legume and vegetable based soup powder from $65.193-69.103 \mathrm{mg} / 100 \mathrm{~g}$ sample during 6 months storage at room temperature.

Mold growth. With reference to the statistical analysis in Table 5, results obviously demonstrate that highly significant differences were observed in the mold count of various treatments of sesame bars with different concentrations of defatted sesame flour at storage intervals $(0,30,60$ and 90 days $)$ at room temperature. As presented in Table 5, the highest mean values of mold count was $7.63 \times 10^{2} \pm 3.6 \mathrm{CFU} / \mathrm{g}$ for $\mathrm{T}_{4}$ and the least was $3.275 \times 10^{2} \pm 2.76 \mathrm{CFU} / \mathrm{g}$ for $\mathrm{T}_{0}$. The results show that an increase in mold count was not related to increasing concentrations of defatted sesame flour in treatments $\mathrm{T}_{3}$ and $\mathrm{T}_{4}$ show higher mold growth (3.160 and $\left.3.600 \times 10^{2}\right)$ as compared to treatments $\mathrm{T}_{0}$ and $\mathrm{T}_{1}$ $\left(3.275 \times 10^{2} \pm 2.76\right.$ and $\left.6.65 \times 10^{2} \pm 2.99\right)$. This can possibly be due to the cooking treatment in $\mathrm{T}_{0}$ and $\mathrm{T}_{1}$ which undoubtedly perishes the mold present up to an extent. Highly significant effect of storage and storage treatment interaction on mold count of sesame bars are deducted from the mean values for storage change periodically from $0.282-7.065 \times 10^{2} \pm 0.02 \mathrm{CFU} / \mathrm{g}$ at 0 and 90 days, respectively. Thereby increased the mold growth significantly during storage for 3 months at ambient temperature but within tolerable limitations. 
Table 5: Effect of treatments and storage on mold count (CFU/g) of sesame bars

\begin{tabular}{llllll}
\hline \hline Treatments & \multicolumn{5}{c}{ Mold count (CFU/g) storage intervals } \\
\cline { 2 - 5 } & $\mathrm{S}_{0}$ & $\mathrm{~S}_{30}$ & $\mathrm{~S}_{60}$ & $\mathrm{~S}_{90}$ & Means \\
\hline $\mathrm{T}_{0}$ & $0.28 \pm 0.02$ & $0.95 \pm 0.04$ & $4.91 \pm 0.34$ & $6.95 \pm 0.13$ & $3.27 \pm 2.76 \mathrm{~d}$ \\
$\mathrm{~T}_{1}$ & $0.22 \pm 0.04$ & $0.50 \pm 0.06$ & $4.61 \pm 0.12$ & $6.65 \pm 0.42$ & $6.65 \pm 2.99 \mathrm{c}$ \\
$\mathrm{T}_{2}$ & $0.41 \pm 0.03$ & $1.51 \pm 0.02$ & $5.13 \pm 0.24$ & $7.14 \pm 0.31$ & $3.55 \pm 2.71 \mathrm{e}$ \\
$\mathrm{T}_{3}$ & $0.11 \pm 0.02$ & $0.65 \pm 0.04$ & $4.93 \pm 0.31$ & $6.94 \pm 0.17$ & $6.94 \pm 2.87 \mathrm{~b}$ \\
$\mathrm{~T}_{4}$ & $0.38 \pm 0.01$ & $0.79 \pm 0.07$ & $5.59 \pm 0.42$ & $7.63 \pm 0.24$ & $7.63 \pm 3.6 \mathrm{a}$ \\
Means & $0.28 \pm 0.11 \mathrm{c}$ & $0.88 \pm 0.35 \mathrm{c}$ & $5.03 \pm 0.32 \mathrm{~b}$ & $7.06 \pm 0.32 \mathrm{a}$ & \\
\hline \hline
\end{tabular}

Means carrying same letters in the column do not differ significantly; Means carrying same letters in the row do not differ significantly; CFU = colony forming unit.

The varied increase in mold growth during storage for different treatments is in consistency with the findings of Al-Hooti et al. (1997b), who accounted that mold growth increased significantly in all treatments during 6 months storage ranging from $2.60-3.00 \times 10^{2} \mathrm{CFU} / \mathrm{g}$ of sesame bar samples.

Calorific value. With reference to the statistical analysis in Table 6, results obviously demonstrate that highly significant differences were observed in the calorific value of various treatments of sesame bars with different concentrations of defatted sesame flour at storage intervals $(0,30,60$ and 90 days) at room temperature. The highest mean value of gross energy was $5355.5 \pm$ $336.9 \mathrm{Kcal} / \mathrm{g}$ for $\mathrm{T}_{4}$ and the least was $3445.9 \pm 312.4$ $\mathrm{Kcal} / \mathrm{g}$ for $\mathrm{T}_{0}$ (Table 6 ). The results gives the evidence that an increase in calorific value was not related to increasing concentrations of defatted sesame flour in treatments $\mathrm{T}_{3}$ and $\mathrm{T}_{4}(4488.2 \pm 207.6 \mathrm{Kcal} / \mathrm{g}$ and $5355.5 \pm 336.9 \mathrm{Kcal} / \mathrm{g}$ ) show higher gross energy as compared to treatments $\mathrm{T}_{0}$ and $\mathrm{T}_{1}(3445.9 \pm 312.4 \mathrm{Kcal} / \mathrm{g}$ and $3602.4 \pm 291.3 \mathrm{Kcal} / \mathrm{g})$. Highly significant effect of storage and storage-treatment interaction on gross energy of sesame bars are deducted from the mean values for storage change periodically from $3813.0 \pm 691.2 \mathrm{Kcal} / \mathrm{g}$ to $4484.7 \pm 725.6 \mathrm{Kcal} / \mathrm{g}$ at 0 and 90 days, respectively. Increase in gross energy, is thereby highly significant, during storage for 3 months at ambient temperature. Results are in accordance with Gandhi and Taimini (2009) who reported that gross energy increased in storage conditions in sesame bars.

Sensory evaluation of sesame bars. Sensory evaluation happens to be the most essential part of the product development and assessment, which reveals the consumer preferences at the initial stages of developing an innovative product like the defatted sesame flour supplemented food bars. It was carried out to evaluate the response of judges towards the product and their likings were recorded on a hedonic scale. Sesame bars were assessed for colour, flavour, texture, crispiness, chewability and overall acceptability during 90 days of storage periods after every 30 days interval.

Colour. Colour reveals the first impression of a food product before consumed. It is the first score of a likeable and disliked food commodity. Results depict that the

Table 6: Effect of treatments and storage on calorific value of sesame bars

\begin{tabular}{llllll}
\hline \hline Treatments & \multicolumn{5}{c}{ Energy value (Kcal/g) storage intervals } \\
\cline { 2 - 5 } & $\mathrm{S}_{0}$ & $\mathrm{~S}_{30}$ & $\mathrm{~S}_{60}$ & $\mathrm{~S}_{90}$ & Means \\
\hline $\mathrm{T}_{0}$ & $3059.4 \pm 54.12$ & $3265.6 \pm 38.72$ & $3574.5 \pm 27.24$ & $3884.3 \pm 30.67$ & $3445.9 \pm 312.4 \mathrm{e}$ \\
$\mathrm{T}_{1}$ & $3221.7 \pm 36.85$ & $3444.9 \pm 32.92$ & $3760.1 \pm 29.86$ & $3983.0 \pm 52.49$ & $3602.4 \pm 291.3 \mathrm{~d}$ \\
$\mathrm{~T}_{2}$ & $3611.6 \pm 48.92$ & $3732.8 \pm 29.85$ & $3848.9 \pm 31.76$ & $3990.1 \pm 42.24$ & $3795.8 \pm 140.0 \mathrm{c}$ \\
$\mathrm{T}_{3}$ & $4243.2 \pm 62.06$ & $4353.0 \pm 31.67$ & $4573.7 \pm 41.34$ & $4782.8 \pm 30.82$ & $4488.2 \pm 207.6 \mathrm{~b}$ \\
$\mathrm{~T}_{4}$ & $4929.1 \pm 49.92$ & $5143.5 \pm 29.34$ & $5565.7 \pm 43.97$ & $5783.6 \pm 28.78$ & $5355.5 \pm 336.9 \mathrm{a}$ \\
Means & $3813 \pm 691.2 \mathrm{~d}$ & $3988 \pm 685.6 \mathrm{c}$ & $4264.6 \pm 733.7 \mathrm{~b}$ & $4484.7 \pm 725.6 \mathrm{a}$ & \\
\hline \hline
\end{tabular}

Means carrying same letters in the column do not differ significantly; Means carrying same letters in the row do not differ significantly. 
colour score differed highly significant among different treatments. These treatments of sesame bars containing varied concentrations of defatted sesame flours at regular intervals of storage $(0,30,60$ and 90 days $)$ at ambient temperature were statistically analysed for colour evaluation as shown in Table 8 . The results pertaining to mean score for the sesame bars in Table 8 revealed that $\mathrm{T}_{2}(7.85 \pm 0.13)$ was most preferred by judges regarding colour followed by $\mathrm{T}_{1}(6.32 \pm 0.14)$. This could be due to the acceptable range of defatted sesame flour addition in the two treatments. Though remaining treatments got fewer score, yet they were acceptable having a reduced colour score in $\mathrm{T}_{0}(5.63 \pm 0.17)$ and $\mathrm{T}_{4}(5.40 \pm 0.12)$, a highly significant effect of storage on colour score of sesame bars. Communally, it was observed that sesame bars were more readily accepted having the maximum scores which were decreased from $5.92 \pm 0.92$ to $6.58 \pm 0.35$ after 90 days storage (Table 9 ). The decrease in colour score might possibly be due to non enzymatic browning within storage period. There was a highly significant effect of treatment and storage interaction on colour score of sesame bars. A decrease in colour score from 6.8-6.2 during storage of 6 months in sesame bars was recounted by Al-Hooti et al. (1997b), whose findings were in concurrence with the changes in colour of sesame bars during their storage period. The colour of sesame bars significantly affected by storage periods, according to Ahmed and Ramswamy
(2005). They illustrated that colour score varied from 6.6-6.2 during storage of 6 months at ambient temperature.

Flavour. Flavour is combination of taste and aroma which as a matter of fact compiles the acceptability of food product under a single sensory attribute. Flavour differed highly significant amongst different treatments on their statistical analysis as shown in Table 8, containing different concentrations of defatted sesame flour at storage intervals $(0,30,60$ and 90 days). The results concerning to mean score for the sesame bars presented in Table 8 , revealed that $\mathrm{T}_{2}(8.40 \pm 0.47)$ was favoured by the panel of judges among the sesame bars treatments, followed by $\mathrm{T}_{0}(6.25 \pm 0.82)$ regarding flavour. This could be due to the satisfactory proportions of defatted sesame flour in the two treatments. Though remaining treatments got fewer score, yet they were acceptable having a reduced flavour score in $\mathrm{T}_{1}(5.37 \pm 0.72)$ and $\mathrm{T}_{4}(5.4 \pm 0.12)$. There was a highly significant effect of storage and significant effect of treatment-storage interaction on flavour of sesame bars. Collectively, the highest scores were observed in fresh sesame bars that gradually increased from $5.82 \pm 0.53$ to $6.56 \pm 0.43$ after 90 days storage presented in Table 9. A decrease in flavour from 6.8-6.3 storage of 6 months in sesame bars was observed by Al-Hooti et al. (1997b) which was in accordance to the change of flavour during

Table 7: Effect of storage on physical analysis of sesame bars

\begin{tabular}{lllll}
\hline \hline Storage intervals & \multicolumn{4}{l}{ Sensory evaluation parameters } \\
\cline { 2 - 5 } & Water activity (Aw) & Hardness $(\mathrm{g})$ & Fracturability $(\mathrm{mm})$ & Colour $(\mathrm{CTn})$ \\
\cline { 2 - 5 } $\mathrm{S}_{0}$ & $0.5363 \pm 0.08 \mathrm{a}$ & $645.17 \pm 15.58 \mathrm{a}$ & $76.707 \pm 3.21 \mathrm{~d}$ & $125.60 \pm 6.21 \mathrm{~d}$ \\
$\mathrm{~S}_{30}$ & $0.5315 \pm 0.03 \mathrm{~b}$ & $517.80 \pm 20.14 \mathrm{~b}$ & $85.487 \pm 3.53 \mathrm{c}$ & $135.60 \pm 5.93 \mathrm{c}$ \\
$\mathrm{S}_{60}$ & $0.5013 \pm 0.75 \mathrm{c}$ & $407.74 \pm 18.93 \mathrm{c}$ & $89.765 \pm 6.21 \mathrm{~b}$ & $145.60 \pm 2.56 \mathrm{~b}$ \\
$\mathrm{~S}_{90}$ & $0.4905 \pm 0.67 \mathrm{~d}$ & $388.14 \pm 22.12 \mathrm{~d}$ & $99.223 \pm 2.86 \mathrm{a}$ & $155.60 \pm 7.23 \mathrm{a}$ \\
\hline \hline
\end{tabular}

Means carrying same letters in a column for each factor do not differ significantly.

Table 8: Effect of treatments on sensory evaluation of sesame bars

\begin{tabular}{lllllll}
\hline \hline Treatment & \multicolumn{7}{c}{ Sensory evaluation parameters } \\
\cline { 2 - 7 } & Colour & Flavour & Texture & Crispiness & Chewability & $\begin{array}{l}\text { Overall } \\
\text { acceptability }\end{array}$ \\
& & & & & & \\
$\mathrm{T}_{0}$ & $5.63 \pm 0.17 \mathrm{~d}$ & $6.25 \pm 0.82 \mathrm{~b}$ & $5.38 \pm 0.09 \mathrm{e}$ & $5.91 \pm 0.45 \mathrm{~d}$ & $5.62 \pm 0.23 \mathrm{~b}$ & $5.80 \pm 0.24 \mathrm{~d}$ \\
$\mathrm{~T}_{1}$ & $6.32 \pm 0.14 \mathrm{~b}$ & $5.37 \pm 0.72 \mathrm{~d}$ & $6.40 \pm 0.03 \mathrm{~b}$ & $6.36 \pm 0.36 \mathrm{c}$ & $5.50 \pm 0.13 \mathrm{~cd}$ & $6.40 \pm 0.23 \mathrm{~b}$ \\
$\mathrm{~T}_{2}$ & $7.85 \pm 0.13 \mathrm{a}$ & $8.40 \pm 0.47 \mathrm{a}$ & $7.67 \pm 0.05 \mathrm{a}$ & $7.92 \pm 0.25 \mathrm{a}$ & $8.42 \pm 0.72 \mathrm{a}$ & $7.93 \pm 0.12 \mathrm{a}$ \\
$\mathrm{T}_{3}$ & $6.07 \pm 0.18 \mathrm{c}$ & $5.60 \pm 0.13 \mathrm{c}$ & $5.50 \pm 0.07 \mathrm{~d}$ & $6.55 \pm 0.43 \mathrm{~b}$ & $5.45 \pm 0.23 \mathrm{~d}$ & $5.95 \pm 0.82 \mathrm{c}$ \\
$\mathrm{T}_{4}$ & $5.40 \pm 0.12 \mathrm{e}$ & $5.37 \pm 0.09 \mathrm{~d}$ & $5.65 \pm 0.04 \mathrm{c}$ & $5.70 \pm 0.28 \mathrm{e}$ & $5.57 \pm 0.23 \mathrm{bc}$ & $5.32 \pm 0.64 \mathrm{e}$ \\
\hline \hline
\end{tabular}

Means carrying same letters in a column for each factor do not differ significantly 
Table 9: Effect of storage on sensory evaluation of sesame bars

\begin{tabular}{|c|c|c|c|c|c|c|}
\hline \multirow[t]{2}{*}{ Storage intervals } & & \multicolumn{4}{|c|}{ Sensory evaluation parameters } & \multirow[b]{2}{*}{$\begin{array}{l}\text { Overall } \\
\text { acceptability }\end{array}$} \\
\hline & Colour & Flavour & Texture & Crispiness & Chewability & \\
\hline $\mathrm{S}_{0}$ & $5.92 \pm 0.92 \mathrm{~d}$ & $5.82 \pm 0.53 \mathrm{~d}$ & $5.72 \pm 0.21 \mathrm{~d}$ & $6.10 \pm 0.72 \mathrm{~d}$ & $5.83 \pm 0.67 \mathrm{~d}$ & $5.96 \pm 0.27 \mathrm{~d}$ \\
\hline $\mathrm{S}_{30}$ & $6.14 \pm 0.83 \mathrm{c}$ & $6.10 \pm 0.32 \mathrm{c}$ & $6.00 \pm 0.92 \mathrm{c}$ & $6.35 \pm 0.66 \mathrm{c}$ & $6.01 \pm 0.54 \mathrm{c}$ & $6.16 \pm 0.51 \mathrm{c}$ \\
\hline $\mathrm{S}_{60}$ & $6.38 \pm 0.43 \mathrm{~b}$ & $6.32 \pm 0.46 \mathrm{~b}$ & $6.24 \pm 0.25 \mathrm{~b}$ & $6.63 \pm 0.87 \mathrm{~b}$ & $6.25 \pm 0.24 \mathrm{~b}$ & $6.40 \pm 0.72 b$ \\
\hline $\mathrm{S}_{90}$ & $6.58 \pm 0.35 \mathrm{a}$ & $6.56 \pm 0.43 \mathrm{a}$ & $6.52 \pm 0.92 \mathrm{a}$ & $6.88 \pm 0.44 \mathrm{a}$ & $6.36 \pm 0.33 \mathrm{a}$ & $6.60 \pm 0.45 \mathrm{a}$ \\
\hline
\end{tabular}

Means carrying same letters in a column for each factor do not differ significantly

storage of various sesame bars samples. (Ahmad and Ramaswany, 2005) reported that storage periods have significant effect on flavour of fruit bars. It was recorded that, flavour acceptability varied from 7.1-6.9 during storage at ambient temperature.

Texture. Texture of sesame bars when statistically analysed, showed highly significant difference amongst different treatments containing different concentrations of defatted sesame flour at storage intervals $(0,30,60$ and 90 days) at ambient temperature signified in (Table $8)$. The mean score findings for texture of the sesame bars given in Table 8 revealed that $\mathrm{T}_{2}(7.67 \pm 0.05)$ was favoured by the judges followed by $\mathrm{T}_{1}(6.40 \pm 0.03)$, which could probably be owing to increased amount of defatted sesame flour in a greater quantity in $T_{2}$ and $T_{1}$ has given a better compact texture to the sesame bars which may be due to lesser moisture content in the treatments as compared to the $\mathrm{T}_{3}$ and $\mathrm{T}_{4}$. Significant texture rating in $\mathrm{T}_{3}(5.50 \pm 0.07)$ and $\mathrm{T}_{4}(5.65 \pm 0.04)$ were collected but they were favourably within satisfactory confines. There was a highly significant effect of storage on texture of sesame bars as well. In general, the maximum scores observed have been presented in Table 9, fresh sesame bars but highly significant effect on storage thus gradually increased them from $5.72 \pm 0.21$ to $6.52 \pm 0.92$. There was nonsignificant effect of treatment and storage interaction on texture of sesame bars. A significant decrease in texture from 6.9-5.9 during storage of 6 months was reported by Al-Hooti et al., (1997b) which happened to be in conformity with variations in the texture of the sesame bars.

Crispiness. Crispiness of sesame bars when statistically analysed showed highly significant difference amongst different treatments containing different concentrations of defatted sesame flour at storage intervals $(0,30,60$ and 90 days) at ambient temperature signified in Table 8. The mean score findings for texture of the sesame bars in Table 8 reveal that $\mathrm{T}_{2}(7.92 \pm 0.25)$ was favored by the judges followed by $\mathrm{T}_{3}(6.55 \pm 0.43)$, which could probably be owing to increased amount of defatted sesame flour in a greater quantity in $\mathrm{T}_{2}$ and $\mathrm{T}_{3}$ has given a better compact crispiness $(7.92 \pm 0.25$ and $6.55 \pm 0.43)$ to the sesame bars which may be due to lesser moisture content in the treatments as compared to the $\mathrm{T}_{1}$ and $\mathrm{T}_{4}$ $(6.36 \pm 0.36$ and $5.70 \pm 0.28)$. Significant crispiness rating in $T_{1}(6.36 \pm 0.36)$ and $T_{4}(5.70 \pm 0.28)$ were collected but they were favourably within satisfactory confines. There was a significant effect of storage on crispiness of sesame bars as well. In general, the maximum scores were observed in fresh sesame bars but highly significant effect on storage thus gradually increased them from $6.10 \pm 0.72$ to $6.88 \pm 0.44$ (Table 9). There was non-significant effect of treatment and storage interaction on crispiness of sesame bars. A significant increase in crispiness from 5.5-6.7 during storage of 6 months was reported by Al-Hooti et al. (1997b) which happened to be in conformity with variations in the crispiness of the sesame bars.

Chewability. Chewability of sesame bars when statistically analyzed showed highly significant difference amongst different treatments containing different concentrations of defatted sesame flour at storage intervals $(0,30,60$ and 90 days) at ambient temperature signified as in Table 8 . The mean score findings for texture of the sesame bar in Table 8 reveal that, $\mathrm{T}_{2}(8.42 \pm 0.72)$ was favuored by the judges followed by $\mathrm{T}_{0}(5.62 \pm 0.23)$, which could probably be owing to increased amount of defatted sesame flour in $\mathrm{T}_{2}$ and $\mathrm{T}_{0}(8.42 \pm 0.72$ and $5.62 \pm 0.23)$ has resulted a compact chewability to the sesame bars due to lower moisture content in the treatments as compared to the $\mathrm{T}_{1}$ and $\mathrm{T}_{4}(5.50 \pm 0.13$ and 5.57 \pm 0.23$)$. Significant chewability rating in $\mathrm{T}_{1}(5.50 \pm 0.13)$ and $\mathrm{T}_{4}(5.57 \pm$ 0.23 ) were collected but they were favourably within satisfactory confines. There was a highly significant 
effect of storage on chewability of sesame bars as well. In general, the maximum scores were observed in Table 9, fresh sesame bars but highly significant effect on storage resulted from $5.83 \pm 0.67-6.36 \pm 0.33$. There was significant effect of treatment and storage interaction on overall acceptability of sesame bars.

The findings of Al-Hooti et al. (1997b), showed significant increases in chewability of sesame bars from 6.2-6.9 during storage of 6 month. The results are in accordance with the alteration of chewability during storage for various sesame bar treatments.

Overall acceptability of sesame bars. The quality scores obtained from the evaluation of colour, flavour, texture, crispiness, chewability and overall acceptability, whose statistical analysis at storage intervals $(0,30,60$ and 90 days) is illustrated in Table 8 . Results reveal that the overall acceptability differed highly significant among different treatments. The results related to mean score for the sesame bar in Table 8 revealed that $\mathrm{T}_{2}(7.93 \pm$ $0.12)$ was preferred by the judges followed by $T_{1}(5.80$ $\pm 0.24)$ regarding overall acceptability. This could be due to the acceptable range of defatted sesame flour addition in the two treatments. Though having a reduced score in $\mathrm{T}_{3}(5.95 \pm 0.82)$ and $\mathrm{T}_{4}(5.32 \pm 0.64)$ resulted in greater acceptability of the sesame bars. There was a highly significant effect of storage on overall acceptability of sesame bars. Collectively, the maximum scores were observed in Table 9 fresh bars that gradually increased from $5.96 \pm 0.27$ to $6.60 \pm 0.45$ after 90 days storage. There was non-significant effect of treatment and storage interaction on overall acceptability of the sesame bars. The findings of Al-Hooti et al. (1997a) who reported significant increase in overall acceptability of sesame bars from 6.9 to 7.9 during storage of 6 months are in accordance with the alteration of overall acceptability during storage for various sesame bars treatments.

\section{Conclusion}

Protein energy malnutrition can be overcomed by the provision of healthy, tasty, convenient and nutritious sesame snack bars. In the current scenario, development of nutritious bars is a good substitute to other junk foods. Sesame snack bars have great market potential to boost up energy and maintain performance by providing minerals, vitamins, fat, protein and carbohydrates. Sesame supplemented bar can be used for the school nutrition programmes to uplift the nutritional status of the school going children.

\section{References}

AACC, 2000. Official Methods of Analysis. American Association of Cereal Chemists, Inc. St. Paul, Minnesota, USA.

Abdel-Aal, E.S.M., Hucl, P. 2002. Amino acid composition and in vitro protein digestibility of selected ancient wheats and their end products. Journal of Food Composition and Analysis, 15: 737-747.

Ahmad, J., Ramaswany, H.S. 2005. Effect of temperature on dynamic rheology and color degradation kinetics of sesame flour. Food Bioproducts Process, 83: 198-202.

Al-Hooti, S., Sidhu, J.S., Al Otaibi, J., Al-Ameeri, H., Qabazard, H. 1997a. Processing of cereals and nuts into chutney and salads. Journal of Food Processing and Preservation, 21: 55-68.

Al-Hooti, S., Sidhu, J.S., Al Otaibi, J., Al-Ameeri, H., Qabazard, H. 1997b. Cereal and nuts bars fortified with almonds, sesame seeds, oat flakes and skim milk powder. Plant Foods for Human Nutrition, 51: 125-135.

Alobo, F.P. 2001. Effect of Sesame Seed Flour on Millet Biscuit Characteristics, 321 pp., Kluwer Academic Publishers, The Netherlands.

AOAC, 2006. Official Methods of Analysis, $20^{\text {th }}$ edition, Association of Official Analytical Chemists, AOAC, Arlington, USA.

AOAC, 1998. Official Methods of Analysis, $18^{\text {th }}$ edition, Association of Official Analytical Chemists, AOAC intranet. Gaithersburg, MD, USA.

Atasie, V.N., Akinhanmi, T.F., Ojiodu, C.C. 2009. Proximate analysis and physio-chemical characteristics of groundnut (Arachis hypogaea L.). Pakistan Journal of Nutrition, 78: 194-197.

Chillo, S., Laverse, J., Falcone, P.M., Protopapa, A., Nobile, M.A.D. 2008. Influence of the addition of buckwheat flour and durum wheat bran on spaghetti quality. Journal of Cereal Science, 47: 144-152.

Cubadda, F., Aureli, F., Raggi, A., Carcea, M. 2009. Effect of milling, pasta making and cooking on minerals in durum wheat. Journal of Cereal Science, 49: 92-97.

Estevez, A.M., Escobar, B., Tepper, A., Castillo, E. 1998. Storage and use of antioxidants in cereal and peanut bars. Archivos Latinoam Nutrition, 48: 160164.

Gandhi, A.P., Taimini, V. 2009. Organoleptic and nutritional assessment of sesame (Sesame indicum, 
L.) biscuits. Asian Journal of Food and AgroIndustries, 2: 87-92.

Goni, I., Valentin-Gamazo, C. 2002. Chickpea flour ingredient shows glycemic response to pasta in healthy volunteers. Food Chemistry, 81: 511-515.

Hahm, T.S., Park, S.J., Martin, Y.L. 2009. Effects of germination on chemical composition and functional properties of sesame (Sesamum indicum L.) seeds. Bioresource Technology, 100: 1643-1647.

Hussein, A.M.S., Kamil, M.M., Mohamed, G.F. 2011. Physicochemical and sensorial quality of semolina defatted guava seed flour composite pasta. Journal of American Science, 7: 623-629.

Ismail, B., Haffer, I., Baalbaki, R., Henry, J. 2008. Physicochemical characteristics and sensory quality of sesame flour biscuits under commercial and industrial storage conditions. Food Science and Technology, 46: 102-106.

Izzo, M., Niness, K. 2001. Formulating nutritious bars with inulin and oligo-fructose. Cereal Food World, 46: $102-106$.

Khalil, J.K. 1986. Cereal bars fortified with nut proteins and dry skim milk. Journal of Cereal Science, 2: 143-165.

Krishna, G., Ranjhan, S.K. 1981. Gross energy of the herbage, urine, milk and silage. In: Laboratory Manual of Nutrition Research. Vikas Publishing House, Dehli, India.

McMahon, D.J., Adams S.L., McManus, W.R. 2002. Hardening of High Protein Bars and Sugar/PolyProtein Phase Separation, 334-341 pp. Department of Nutrition and Food Science, Utah State University, USA.

Meilgaard, M.D., Civille, G.V., Carr, B.T. 2006. Sensory Evaluation Techniques. 4th edition. CRC Press, Boca Raton, FL, USA.

Onsaard, E., Pomsamud, P., Audtum, P. 2010. Functional properties of sesame protein concentrates from sesame meal. Journal of Food and Agro-Industries, 3: $420-431$.
Palumbo, M., Spina, A., Boggini, A. 2002. Breadmaking quality of Italian durum wheat (Triticum durum) cultivars. Italian Journal of Food Science, 14: 123-133.

Piga, A., Catzeddu, S., Farris, T., Roggio, A., Scano, E., 2005. Texture evolution of "Amaretti” cookies during storage. European Food Research and Technology, 221: 387-391.

Rehman, M.S., Al- Farsi, S.A. 2005. Instrumental texture profile analysis (TPA) of date flesh as a function of moisture content. Journal of Food Engineering, 66: $510-511$.

Rocha, A.M.C.N, Morais, A.M.M.B. 2003. Shelf life of minimally processed apple determined by color change. Food Control, 14: 13-20.

Rokhsana, F., Yeasmin, R., Nahar, A. 2007. Studies on the development and storage stability of legume and vegetable based soup powder. Bangladesh Journal of Agricultural Research, 32: 451-459.

Shakeel, M., Abdullah, M., Akhtar, M.N., Nasir, M. 2009. Nutritional improvement and value-addition of buffalo milk kurut with soya protein isolate. Pakistan Journal of Zoology, 9: 389-395.

Steel, R.G.D., Torrie, J.H., Dickey, D.A. 1997. Principles and Procedures of Statistics: A Biometrical Approach. $3^{\text {rd }}$ edition, McGraw Hill Book Co. Inc., New York, USA.

Umar, S. 2006. Alleviating adverse effects of water stress on yield of sorghum, mustard and various acyl lipid, Tocopherols and lignans in sesame seed oil roasted in a microwave oven. Journal of Agriculture and Food Science, 68: 407-415.

Vincent, O.S., Adewale, I.T., Rachael, O.D.A., Bolanle, J.O. 2009. Proximate and mineral composition of roasted and defatted cashew nut (Anarcadium occidentale L.) flour. Pakistan Journal of Nutrition, 8: $1649-1651$.

Yip, R., Dallman, P.R. 1996. Iron: Present Knowledge in Nutrition. pp 277-292, $7^{\text {th }}$ edition, ILSI Press, Washington DC, USA. 